\title{
Sowing Date and Pesticide Application Effects on Barley Grown in Central Ethiopia
}

\author{
Girma Gemedi ${ }^{1} \quad$ Woldeyesus Sinebo ${ }^{2} \quad$ Ketema Belete $^{3}$ \\ 1.Ethiopian Agricultural Businesses Corporation-Ethiopian Seed and Natural Forest Supply Sector \\ 2.Ethiopian Institute of Agricultural Research, P.O. Box 2003, Addis Ababa; 3 Haramaya University, P. O. Box \\ 138, Dire Dawa, Ethiopia
}

\begin{abstract}
We evaluated the effects of sowing dates and pesticide (control or insecticidal seed treatment with Imidacloprid plus foliar fungicide Propiconazole) application on four barley varieties. Sowing dates, pesticide application and variety significantly affected yield, yield components, shoot fly incidence and fungal disease score. Variety HB1307 gave significantly greater seed yield than the other three varieties. June 26 sowing gave significantly more grain yield than earlier or later sowings. Spike density per unit area was lower with the June 15 and July 18 sowings than with June 26 and July 7 sowings. Barley shoot fly infestation decreased with delay in sowing date. Grain yield increased from 3264 to $4117 \mathrm{~kg} / \mathrm{ha}$ due to pesticide application. Seed dressing decreased insect damage and increased spikes $\mathrm{m}^{-2}$. Foliar fungicide application reduced fungal disease score. Grain yield of HB-1307 was less by about $2800 \mathrm{~kg} / \mathrm{ha}$ when sown early or late without the pesticides. Results for sowing dates and pesticide application from the current study concur with similar studies conducted in the same environment in earlier years. Crop management packages that include choice of the best variety, optimal sowing date and adequate control of insect pests and diseases can dramatically increase barley grain yield in central Ethiopia.
\end{abstract}

Keywords: insecticidal seed treatment, fungicide application, integrated pest management

DOI: $10.7176 / \mathrm{JNSR} / 10-1-06$

Publication date: January $31^{\text {st }} 2020$

\section{Introduction}

Barley in Ethiopia is a major cereal food crop grown by subsistence farmers in the highlands especially above altitudes of $2300 \mathrm{~m}$ mainly under rain fed conditions with minimum or no external inputs (Yirga et al., 2002). In spite of the huge importance of barley as food and malt, its productivity is quite low, averaging only $1.3 \mathrm{t} / \mathrm{ha}$ (Mulat and Grando, 2011), which contrasts with the world average of $2.4 \mathrm{t} / \mathrm{ha}$. The low productivity of the crop is associated with multidimensional abiotic and biotic stress factors (Lakew et al., 1996; Molla and Gebre, 1996), which includes season-end moisture stress, barley shoot fly (Delia arambourgi (Seguy)) and fungal diseases such as scald, rust and leaf blotches (Molla and Gebre, 1996; Sinebo, 2002; Sinebo, 2005; Sinebo et al., 2010).

While sowing barley late in the season exposes the crop to terminal drought stress during grain filling, early sowing is known to intensify attack by shoot fly and promote the development of fungal leaf diseases, in the end, resulting in lower yield. Such yield reduction can be minimized through integration of chemical crop protection with other crop management practices such as choice of appropriate sowing dates.

Sinebo (2005) and Sinebo et al. (2010) reported that in some years season-end drought is a major threat to increasing barley yield in the central highlands of Ethiopia. Early sowing may help the crop escape season-end drought and may allow longer crop duration leading to larger biomass accumulation perhaps resulting in greater economic yield. However, a few sowing date trials conducted on barely at Holetta failed to establish the superiority for grain yield of early sowing. Insects such as barley shoot fly and diseases such as scald, leaf blotches, and rust were reported as major problems when barley is sown early in June at Holetta (Molla and Gebre, 1996). Nevertheless, whether the control of insects and diseases by the application of appropriate pesticides would lead to greater yields from early sowing has not been established.

Losses caused by pests may be minimized by cultural practices. However, pesticides are also an integral part of pest management and essential to maximize cop yield. It has been reported that seed treatment with systemic insecticides such as imidacloprid (Gaucho ${ }^{\circledR}$ ) protects seeds and seedlings of agricultural crops against injury by insects (Tharp et al., 2000; Tomlin, 2000; Wilde et al., 2004) and, in the end result, in greater yields of crops such as barley.

Propiconazole is a fungicide used to control leaf diseases of barley and other cereal crops. Bekele et al. (2004) and Van Den Berg and Rossanage (1989) in barley reported an increase in grain yield and thousand kernel weight as a result of propiconazole application against leaf diseases. Peltonen and Karjalainen (1991) also noted increase in grain nitrogen uptake, grain protein, grain yield and thousand kernel weight due to propiconazole application in wheat. In barley, Woldeab and Agu (2008) reported significantly lower grain yield, thousand kernel weight and kernels per spike in propiconazole unsprayed plots against rust diseases. Sinebo et al. (2010) also reported an increase in barley grain yield due to imidacloprid seed treatment and propiconazole spraying. Tarekegne $e t$ al. (1997) reported a 5\% and 27\% increase in yield of barley due to fungicide Triadmefon and insecticide Aldrin 
application, respectively.

The objective of this study was to evaluate the main and interaction effects of sowing dates and crop protection treatments on yield, yield components, and insect pest and disease incidence of four barley varieties in the central highlands of Ethiopia. Our study specifically tries to figure out whether high barley grain yield could be attained from early sowing provided that shoot fly damage early in the season is managed through insecticidal seed treatment and fungal diseases later in the season are controlled through foliar application of propiconazole. This study, with only four improved widely grown barley varieties, builds on a similar earlier study that, under three sowing dates and two pesticide treatments, evaluated larger number of barley genotypes (39 varieties) comprising landraces, improved varieties, and elite experimental lines (Sinebo et al., 2010).

\section{Materials and Methods}

The experiment was conducted in 2010 main crop growing season on red brown clay (a Euteric Nitosol) at Holetta Agricultural Research Center, $28 \mathrm{~km}$ West of Addis Ababa. Holetta is located at $9^{0} 03^{\prime} \mathrm{N} 38^{0} 31^{\prime}$ East at an altitude of 2400 meters above sea level. The environment is seasonally humid with an average annual rainfall of $1055 \mathrm{~mm}$, $85 \%$ of which is received between the months of June and September. Mean maximum and minimum temperature are 22.2 and $6.1^{\circ} \mathrm{C}$ respectively (Sinebo et al., 2010; Sinebo, 2005).

A split plot arrangement with a factorial combination of four sowing dates and two crop protection treatments in the main plots and the varieties in the sub plots in three replications was used. Two of the varieties (HB-1307 and HB-42) are of food barley type and the remaining two (Holker and Miscal) malt barley varieties (Table 1). The four sowing dates were June 15 and 26 and July 7 and 18. The two crop protection treatments consisted no pesticide or insecticidal seed treatment plus foliar fungicide application. For the pesticide treatment, the fungicide propiconazole (Tilt ${ }^{\circledR}$ ) was applied at a rate of $0.5 \mathrm{l} /$ ha and the insecticide Imidacloprid (Gaucho®) was applied at a rate of $1 \mathrm{~g}$ product per kilogram seed. Dates of sowing and fungicide application are given in Table 1. A plot consisted of 6 rows $20 \mathrm{~cm}$ apart and $2.5 \mathrm{~m}$ long. The four central rows were harvested for yield determination.

Data were collected on growth, yield components, yield, phenology and disease and insect pest incidence and damage. Heading date was recorded as when the spikes of about $50 \%$ of the culms in a plot were fully extruded out. Physiological maturity was recorded when about $75 \%$ of plants in a plot had lost their green color from both vegetative and reproductive tissues. Plant height at maturity was determined from representative plants in a plot by measuring from the ground surface to the tip of the spike excluding the awns. Number of spike per $\mathrm{m}^{2}$ was counted from two central rows of each plot at maturity. Kernel number per spike was determined from representative ten plants in a plot. Shoot fly damage was counted 10 days after emergence for each sowing date. Disease was scored on a $0-9$ scale. In this scale 0 indicates free from infection, 1 indicates resistant with few isolated lesions on lower most leaves, 5 indicates moderate susceptibility with severe infection of lower leaves and 9 high susceptibility with severe infection on all leaves.

Analysis of variance was performed using the GLM procedure of SAS statistical software version 9.0. Persons correlation coefficient was computed among growth, phenological, grain yield and yield components.

\section{Results and Discussion \\ Weather}

In the year 2010, total annual rainfall of $1133.8 \mathrm{~mm}$ was received. The rainfall for the cropping months of June to November 2010 was $851.4 \mathrm{~mm}$ (Table 2), which exceeds the total rainfall recoded for the same months in some other years (Sinebo et al., 2010). The first shower of rain for the month of June was obtained on the 5 th of June $(16.4 \mathrm{~mm})$ followed by three consecutive rainy days from 9th to 11 th of June marking the arrival of the main season rain for the year 2010. In an earlier study, for the period of 2002-2004, Sinebo et al. (2010) reported the window of 6 to 8 June as the period of onset of the main season rain in the three years.

In Holetta area, grain filling for barley crop often takes place during the months of September and October. In the current study, the rainfall for September 2010 was 192.2 (Table 2). The probability of receiving rainfall as high as that in the area was low, amounting to less than $10 \%$ (Sinebo, 2005). Hence, September 2010 was a rainfall rich month. The last fall for September was a $10.5 \mathrm{~mm}$ rain received on the 26th. However, there was no rain during the critical grain filling month of October, which might affected yield for later sowings (Table 3). November saw two rainy days on the 14th $(2.7 \mathrm{~mm})$ and on the 24 th $(21.4 \mathrm{~mm})$ which might helped the last sown crop for better grain filling. Night time (minimum) temperature was higher for the months of June to September, for instance, when compared to the figures reported in our earlier studies (Sinebo et al., 2010).

\section{Growth durations and plant height}

Sowing date and variety had highly significant effects on growth durations and plant height (Tables 3 and 4). Later sowing tended to shorten time to maturity when compared to early sowing. Plants were significantly taller when sown on June 26 followed by July 7 than the first or the last sowings (Table 4). Variety HB-42 grew the tallest and Miscal the shortest of the four varieties. Plants grew significantly taller with the application of pesticides than 
without pesticide (Table 4).

\section{Grain yield and yield components}

Sowing dates and pesticide application significantly affected number of spikes per square meter (SPM), kernel weight (KWT) and grain yield (Tables 3 and 4). The highest number of spikes per square meter, kernel weight and grain yield were obtained from the June 26 sowing (Table 3). Grain yield decreased from a mean maximum of $4404 \mathrm{~kg} / \mathrm{h}$ a for the June 26 sowing to $3556 \mathrm{~kg} / \mathrm{ha}$ for the June 15 sowing or $3157 \mathrm{~kg} / \mathrm{ha}$ for the July 18 sowing (Table 4). Lower grain yield for the June 15 sowing was because of the low SPM presumably resulting from high infestation by shoot fly. Number of spikes per square meter decreased from 311 for June 26 sowing to 256 for June 15 sowing and number of plants visibly damaged by insect increased from 30 for the June 26 sowing to 68 for the June 15 sowing (Table 4).

Pesticide application on average increased SPM from 209 to 309, KWT from 43 to $46 \mathrm{mg}$ and grain yield from 3264 to $4117 \mathrm{~kg} / \mathrm{ha}$. Our result for SPK agrees with the findings of Razzague and Rafiquzzamay (2006), Alam et al. (2006) and Ahmed et al. (2008) who in wheat and barley reported significant effect of sowing date on SPK. Jobie (2003) and Tanner et al. (2004) in experiments conducted on barley and wheat at Sinana, South East Ethiopia reported poor plant population of wheat and barley in years of high barley shoot fly infestation.

Increase in grain yield as a result of pesticide application is in agreement with, Sutton and Steel (1983), Van Den Berg and Rossanage (1989), Bekele et al. (2004) and Getaneh and Agu (2008) all of whom reported barley grain yield increase as a result of the fungicide propiconazole application against leaf rust, spot blotch or net blotch disease. In a more similar experiment with 39 barley varieties, Sinebo et al. (2010) reported average grain yield of $4410 \mathrm{~kg} / \mathrm{ha}$ with pesticide application (insecticidal seed treatment and fungicidal spray) and $3320 \mathrm{~kg} / \mathrm{ha}$ without pesticide application.

In our current study, kernels per spike was not significantly affected by sowing date and pesticide application. This finding is in line with Sutton and steel (1983), Berg and Rossnage (1989) and Getaneh and Agu (2008) who reported absence of significant effect of pesticide application or sowing dates on the number of kernels per spike of barley.

The sowing date by pesticide interaction was not significant for yield and yield components (Table 3 ). However, the sowing date by pesticide interaction being significant only at $10 \%$ probability level was interesting (Figure 1a). The yield difference between pesticide and control treatments were large in the first two sowing dates, smaller in the third sowing date and non-existent in the last sowing date made on 18th of July. This indicates absence of any yield advantage due to pesticide application with late sowing. The highly significant sowing date by pesticide interaction for seedling damage by barley shoot fly (Table 3 and Figure 1b) is consistent with the weak, nonetheless important, interaction observed for grain yield in Figure 1a, indicating lack of advantage of insecticidal seed treatment for barley shoot fly control and thereof grain yield.

Varietal effect was highly significant for yield and yield components. The two food barley varieties (HB1307 and HB-42) gave more grain yield than the two malt barley varieties (Holker and Miscal), with HB-1307 yielding more than the rest (Table 3). HB-1307 and HB-42 had significantly less SPM but significantly more KPS than Holker and Miscal. HB-1307 yielded significantly more than HB-42 because of larger SPM and KWT, which more than compensated for less number of KPS in HB-1307 (Table 4).

Pesticide application increased thousand kernel weight from 43 to $46 \mathrm{~g}$ (Table 4). This result is in harmony with Sutton and Steel (1983), Berg and Rossnage (1989) and Bekele et al. (2004) who in barley reported increase in kernel weight due to propiconazole application. Likewise, Ronis et al. (2009) in winter wheat found increase in thousand kernel weight due to propiconazole application against leaf diseases.

\section{Barley shoot fly damage}

Only sowing date, pesticide and sowing date $\times$ pesticide interaction effects were highly significant for the number of seedlings damaged by shoot fly infestation (Table 3 and Figure 1). Shoot fly infestation was the highest from the earliest sowing ( 68 seedlings per square meter from June 15 sowing) and the lowest from the latest sowing (16 seedlings per square meter from July 18) (Table 4).

Similar results were reported by Adamu et al. (1996) and Sinebo et al. (2010) in the same environment. However, at Sinana, southeastern Ethiopia, Jobie and Mulatu (2011) reported more shoot fly damage from late sowing dates than early sowing dates. Seed treatment with Imidaclopride (Gaucho ${ }^{\circledR}$ ) on average reduced shoot fly incidence from 50 seedlings per square meter to 16 seedlings per square meter (Table 4).

There was a highly significant interaction between sowing date and seed treatment for seedling damage by barley shoot fly (Figure 3). Insecticidal seed treatment mattered most when sowing was early. The importance of insecticidal seed treatment declined with successive delay in sowing, eventually showing no effect at the last sowing made on July 18 (Figure 1b). 


\section{Disease score}

Barley varieties were significantly different for all the four diseases (scald, net blotch, spot blotch and leaf rust) scored (Table 3). The recently diffused popular food barley variety HB-1307 appeared to have the lowest score for three of the four diseases.

Sowing date had significant effect on scald, spot blotch and rust disease scores (Tables 3 and 4). The three diseases tended to decrease with delay in sowing date. Disease score declined with the application of foliar fungicide but the effect was only statistically significant for scald and net blotch.

\section{Conclusion}

The importance of early sowing as a strategy to escape season-end moisture stress was recognized. However, yield advantage from early sowing was hampered by high barley shoot fly infestation and high incidence of diseases. Insecticidal seed treatment and foliar fungicidal spray brought down pest damage and increased grain yield substantially but did not control pests entirely. As a result, the full advantage of early sowing with the advent of rain in this season-end drought prone environment remains unrealized. Among the three yield components, it was apparent that KPS remained stable due to variation in sowing dates and pesticide application. However, it was found that SPM was substantially reduced due to barley shoot fly infestation early in the season and KWT was reduced by leaf diseases and season-end moisture stress both of which affect carbohydrate assimilation and remobilization.

Future barley crop management interventions in central Ethiopian highlands should contend with optimizing SPM and stabilizing KWT in the face of high pest incidence with early sowing and season-end drought stress with late sowing. Finally, our results for sowing dates and pesticide application from this study, by and large, confirm our earlier findings with a more diverse set of barley varieties in the same environment (Sinebo et al., 2010 and unpublished data). Hence, we believe that our conclusions remain robust.

\section{References}

Alam, M. Z., S.A. Haider and N.K. Paul. 2006. Yield and yield components of barley in relation to sowing dates. Journal of Biological Science 15:139-145.

Hunde, B., Somsiri, S. and E.D. Sarobol. 2004. Barley net blotch.(Pyrenophora teres Drechsl.). Epidemiology and management. Kasetsart Journal (Natural Science). 38: 380-392.

Jobie, T. 2003. Mechanisms of resistance in barley accessions to shoot fly (Delia flavibasis) An MSc Thesis presented to the School of Graduate Studies of Alemaya University.

Lakew, B., Gebere, H. and Alemayehu, F. 1996. Barley production and research in Ethiopia. In: Gebere, H. and Van Leure J. (eds.) Barley research in Ethiopia; past and future prospective, Proceedings of the first barley review work shop,16-19 october 1993. Addis Ababa: IAR/ICARDA, Addis Ababa, Ethiopia.McMCKenzie, R. H., A. B. Middleton and E. Bremer. 2005. Fertilization, seeding date, and seeding rate for malting barley yield and quality in southern Alberta. Canadian Journal of Plant Science. 85:603-614.

Molla, A. and Gebre, H. 1996. The relative importance of factors limiting barley production in the highland vertisols at Sheno. Ethiopian Journal of Agricultural Science 15:33-42.

Mulat, B. and Grando, S. 2011. Barley research and development in Ethiopia. Proceedings of the Second National Barley Research and Development Review Workshop. 28-30 November 2006. HARC, Holetta, Ethiopia. ICARDA, PO Box 5466, Aleppo, Syria.

Peltonen, J. and R. Karjalainen. 1992. Effects of fungicide sprays on foliar diseases, yield and quality of spring wheat in Finland. Canadian Journal of Plant Science. 72: 955-963.

Reshid, A., R.U. Khan, S.K. Marwat and Z. Ali. 2010. Response of barley to sowing date and fertilizer application under rain fed condition. World Journal of Agricultural Science. 6(5):480-484.

Ronis, A., R. S., Z. Dabkevičius, Ž. Liatukas. 2009. Influence of leaf diseases on grain yield and yield components in winter wheat. Journal of Plant Protection Research 49(2).

Sacks, W. J., D. Derying, Jonathan A. Foley and N. R., Kutty. 2010. Crop planting dates: An analysis of global patterns. Global Ecology and Bio-geography. 19:607-620.

Sutton, J. C. and P. Steele. 1983. Effects of seed and foliar fungicides on progress of net blotch and yield in barley. Canadian Journal of Plant Sciences. 63: 631-639.

Sinebo, W., Lakew, B. and Feyissa, A. 2010. Biplot analysis of grain yield in barley grown under differing management levels in years of contrasting season-end drought. Journal of Plant Breeding and Crop Science. 2(6):152-164.

Sinebo, W. 2005. Trade off between yield increase and yield stability in three decades of barley breeding in a tropical highland environment. Field Crops Research 92:35-52

Tarekegn, A., Gebre, H. and Francis, C. A. 1997. Yield limiting factors to food barley production in Ethiopia. Journal of Sustainable Agriculture 10:97-113.

Tharp, D., S. L. Blodgett and G. D. Johnson. 2000. Efficacy of imidacloprid for control of cereal leaf beetle 
(Coleopotera: Chrysomelidae) in barley. Journal of Economic Entomology 93: 38-42.

Tomlin, C.D.S. 2000. The pesticide manual. Twelfth Edition. British Crop Protection Council. Surrey, U.K.

Van Den Berg, C. G. J. and Rossanage, B. G. 1990. Effect of Tilt on severity of spot type net blotch, grain yield and yield components in barley. Canadian Journal of Plant Science.70: 473-480.

Wilde, G., K. Roozeboom, M. Claassen, K. Janssen and M. Witt. 2004. Seed treatment for control of early-season pests of corn and its effect on yield. Journal of Agriculture and Urban Entomology 21(2):75-85.

Woldeab, G., Agu, C.M.. 2008. Yield loss due to leaf rust on barley at different sowing dates. Medwell Journals of Plant Sciences Research. 1(2): 40-43.

Yirga, C., Lakew, B., Alemayehu, F. 2002. On-farm evaluation of food barley production packages in the high lands of Welmera and Degem, Ethiopia. Towards farmers participatory research: Attempts and achievements in the central highlands of Ethiopia: In: Proceedings of Client Oriented Research Evaluation Workshop,1618 October 2001, Holetta Agricultural Research Center, Holetta, Ethiopia. EARO.

Table 1. List of varieties, sowing dates and fungicide application dates (for fungicide receiving treatments).

\begin{tabular}{lcl}
\hline Variety & Year of release & Row Type \\
\hline HB-1307 & 2006 & Six \\
HB-42 & 1984 & Six \\
Holker & 1973 & Two \\
Miscal & 2001 & Two \\
& & \\
Sowing date & Fungicide application dates \\
\hline \multicolumn{1}{c}{ 15 June } & 10 August \\
& 25 August \\
\cline { 2 - 2 } 26 June & 21 August \\
& 6 September \\
\cline { 2 - 2 } 7 July & 2 September \\
18 July & 17 September \\
\cline { 2 - 2 } & 15 September \\
\end{tabular}

Table 2. Mean monthly rainfall, minimum and maximum temperature and sunshine hours and relative humidity during 2010 main crop growing season at Holetta, Ethiopia.

\begin{tabular}{lcccccc}
\hline Weather Variables & June & July & August & September & October & November \\
\hline Rainfall $(\mathrm{mm})$ & 93.0 & 287.9 & 206.2 & 192.2 & 0.0 & 24.1 \\
Minimum temperature $\left({ }^{\circ} \mathrm{C}\right)$ & 9.8 & 10.5 & 10.3 & 8.8 & 5.7 & 3.5 \\
Maximum temperature $\left({ }^{\circ} \mathrm{C}\right)$ & 23.8 & 21.7 & 21.0 & 21.0 & 23.9 & 22.9 \\
Sunshine hours & 3.8 & 1.9 & 1.0 & 3.1 & 7.6 & 7.7 \\
Relative humidity $(\%)$ & 73.7 & 72.9 & 86.3 & 85.6 & 51.7 & 44.3 \\
\hline
\end{tabular}

Table 3. Mean square for some agronomic traits of barley grown in the main crop growing season at Holetta in 2010 .

\begin{tabular}{|c|c|c|c|c|c|c|c|c|c|c|c|c|c|c|c|c|}
\hline Source $^{\dagger}$ & dff $\ddagger$ & DTH & DTM & GFP & PHT & SPM & KPS & KWT & BYLD & GYLD & HI & IND & SCL & NEB & SPB & RUS \\
\hline SD & 3 & $431.47^{* * *}$ & $410.36^{* * *}$ & $242.06^{* * * *}$ & $291.46^{* *}$ & $17970^{*}$ & 3.21 & $16.02^{*}$ & $0.3^{*}$ & $0.065^{* *}$ & 0.004 & $13328^{* * *}$ & $15.487^{*}$ & 1.188 & $10.44^{* *}$ & $298.001^{* * *}$ \\
\hline PC & 1 & $48.16^{* *}$ & 22.04 & 3.01 & $226^{*}$ & $60954^{* *}$ & 0.33 & $118.37 * * *$ & $1.06^{* *}$ & $0.174^{* *}$ & 0.003 & $27710^{* * *}$ & $44.415^{* *}$ & $8.476^{*}$ & 3.676 & 90.834 \\
\hline $\mathrm{SD} * \mathrm{PC}$ & 3 & $55.75^{* * * *}$ & 19.95 & 19.28 & $195.07 *$ & 16270 & 19.57 & 11.13 & 0.11 & 0.026 & 0.004 & $5932^{* * *}$ & 3.093 & 1.719 & 1.483 & 48.868 \\
\hline $\mathrm{Ea}$ & 14 & 5.19 & 11.8 & 8.71 & 53.81 & 5038.6 & 39.86 & 4.51 & 0.07 & 0.01 & 0.002 & 138 & 3.367 & 1.342 & 1.609 & 30.289 \\
\hline $\mathrm{v}$ & 3 & $1494.08^{* * *}$ & $304.41^{* * * *}$ & $730.7^{* * *}$ & $3208.9^{* * *}$ & $28129^{* * *}$ & $4902.12^{* * *}$ & $283.98^{* * * *}$ & $0.3^{* * *}$ & $0.1^{* * *}$ & $0.028^{* * *}$ & 164 & $6.838^{* * *}$ & $13.398^{* * * *}$ & $11.456^{* * * *}$ & $725.577 * * *$ \\
\hline $\mathrm{SD}^{*} \mathrm{~V}$ & 9 & $42.87^{* * *}$ & $9.64^{* *}$ & $54.45^{* * *}$ & 67.73 & 3750.14 & 10.27 & 3.98 & 0.017 & 0.004 & 0.0009 & 123 & 1.965 & 1.073 & 0.82 & 66.622 \\
\hline $\mathrm{PC}^{*} \mathrm{~V}$ & 3 & 4.52 & 3.18 & 12.95 & 18.4 & $10852^{* *}$ & 11.14 & 5.14 & 0.028 & 0.007 & 0.0009 & 53 & 0.122 & 0.457 & 0.919 & 19.96 \\
\hline $\mathrm{SD}^{*} \mathrm{PC}^{*} \mathrm{~V}$ & 9 & 6.85 & 2.57 & 9.75 & 3.38 & $5084.38^{*}$ & 40.41 & 1.55 & 0.016 & 0.0034 & 0.062 & 63 & 1.841 & 1.047 & 0.602 & 62.934 \\
\hline $\mathrm{Eb}$ & 48 & 3.42 & 2.72 & 6.02 & 43.93 & 240092 & 22.47 & 3.67 & 0.015 & 0.0035 & 0.0013 & 162 & 1.282 & 1.235 & 0.710 & 104.802 \\
\hline
\end{tabular}

$\uparrow \mathrm{SD}=$ sowing date; $\mathrm{PC}=$ pesticide; $\mathrm{Ea}=$ main plot error; $\mathrm{V}=$ variety; $\mathrm{Eb}=$ subplot error

$\$ \mathrm{df}=$ degree of freedom; DTH=days to heading; $\mathrm{DTM}=$ days to maturity; GFP=grain filling period; PHT=plant height; SPM=spike per meter square; KPS=Kernel per spike; TKW =Thousand kernel weight; BYLD=biological yield; GYLD=grain yield; $\mathrm{HI}=$ harvest index; $\mathrm{IND}=$ insect damage; $\mathrm{SCL}=$ scald (Rhynchosporium secalis) disease score; $\mathrm{NEB}=$ net blotch (Pyrenophora teres $f$. teres) disease score; $\mathrm{SPB}=$ spot blotch (Pyrenophora teres $f$ maculata) disease score; RUS=rust (Puccinia hordei) disease score

$*, * *$ and $* * *$ are significant at probability level of $0.5,0.01$ and 0.001 , respectively. 
Table 4. The main effect of sowing dates and pesticide application on thousand kernel weight, biological yield and grain yield of barley grown at Holeta, Ethiopia in 2010 main crop growing season.

\begin{tabular}{|c|c|c|c|c|c|c|c|c|c|c|c|c|c|c|c|c|}
\hline Treatments & $\operatorname{COT}_{\dagger}^{\prime}$ & DTH & DTM & GFP & PHT & SPM & KPS & KWT & BYLD & GYLD & HI & IND & SCL & NEB & SPB & RUS \\
\hline \multicolumn{17}{|l|}{ Variety } \\
\hline HB-1307 & 137 & 77 & 129 & $52 \mathrm{a}_{\ddagger}^{+}$ & $102 \mathrm{~b}$ & $276 \mathrm{bc}$ & $47 b$ & $45 \mathrm{~b}$ & $11583 a$ & $4617 \mathrm{a}$ & $0.39 \mathrm{a}$ & 32 & $1.85 \mathrm{~b}$ & $0.60 \mathrm{c}$ & $2.65 \mathrm{c}$ & $0.00 \mathrm{c}$ \\
\hline HB-42 & 149 & 89 & 130 & $41 \mathrm{~b}$ & $119 \mathrm{a}$ & $239 \mathrm{c}$ & $53 a$ & $39 \mathrm{c}$ & $11292 \mathrm{ab}$ & $3647 \mathrm{~b}$ & $0.32 \mathrm{c}$ & 35 & $3.12 \mathrm{a}$ & $2.37 \mathrm{a}$ & $4.12 \mathrm{a}$ & $6.34 b$ \\
\hline Holker & 136 & 85 & 127 & $42 \mathrm{~b}$ & $98 \mathrm{~b}$ & $309 a$ & $27 \mathrm{c}$ & $45 \mathrm{~b}$ & $9854 \mathrm{bc}$ & $3193 c$ & $0.32 \mathrm{c}$ & 31 & $2.31 \mathrm{~b}$ & $1.71 \mathrm{~b}$ & $2.54 \mathrm{c}$ & $2.81 \mathrm{bc}$ \\
\hline Miscal & 145 & 71 & 122 & $51 \mathrm{a}$ & $92 \mathrm{c}$ & $312 a$ & $24 \mathrm{c}$ & $48 \mathrm{a}$ & $9223 c$ & $3307 \mathrm{bc}$ & $0.35 b$ & 36 & $2.42 \mathrm{~b}$ & $1.06 \mathrm{c}$ & $3.17 \mathrm{~b}$ & $12.75 \mathrm{a}$ \\
\hline \multicolumn{17}{|l|}{ Sowing date } \\
\hline June 15 & $125 \mathrm{c}$ & $86.1 \mathrm{a}$ & $132 \mathrm{a}$ & $47 \mathrm{~b}$ & $100 \mathrm{~b}$ & $256 \mathrm{c}$ & 38 & $44.5 \mathrm{ab}$ & $9979 \mathrm{~b}$ & $3556 \mathrm{~b}$ & $0.35 \mathrm{ab}$ & $68 \mathrm{a}$ & $3.02 \mathrm{a}$ & 1.40 & $3.75 \mathrm{a}$ & $9.69 \mathrm{a}$ \\
\hline June 26 & $149 \mathrm{a}$ & $77.2 \mathrm{c}$ & $127 \mathrm{~b}$ & $50 \mathrm{a}$ & $107 a$ & $311 \mathrm{a}$ & 37 & $45.2 \mathrm{a}$ & $12125 \mathrm{a}$ & $4404 a$ & $0.36 \mathrm{a}$ & $30 \mathrm{~b}$ & $3.21 \mathrm{a}$ & 1.73 & $3.60 \mathrm{a}$ & $5.11 \mathrm{ab}$ \\
\hline July 7 & $149 a$ & $81.3 \mathrm{~b}$ & $123 \mathrm{c}$ & $42 \mathrm{c}$ & $104 a$ & $303 \mathrm{ab}$ & 38 & $43.9 \mathrm{bc}$ & $10292 b$ & $3647 \mathrm{~b}$ & $0.35 \mathrm{ab}$ & $20 \mathrm{c}$ & $1.77 \mathrm{~b}$ & 1.19 & $2.79 \mathrm{~b}$ & $6.00 \mathrm{ab}$ \\
\hline July 18 & $144 \mathrm{~b}$ & $77.2 \mathrm{c}$ & $124 \mathrm{c}$ & $47 \mathrm{~b}$ & $100 \mathrm{~b}$ & $265 b$ & 38 & $43.3 \mathrm{c}$ & $9563 \mathrm{~b}$ & $3157 \mathrm{c}$ & $0.33 b$ & $16 \mathrm{c}$ & $1.71 \mathrm{~b}$ & 1.40 & $2.33 \mathrm{~b}$ & $1.10 \mathrm{~b}$ \\
\hline \multicolumn{17}{|l|}{ Pesticide } \\
\hline No & 140 & $81 \mathrm{a}$ & 127 & 46 & $101 \mathrm{~b}$ & $259 \mathrm{~b}$ & 38 & $43 b$ & $9438 b$ & $3264 b$ & 0.34 & $50 a$ & $3.12 \mathrm{a}$ & $1.73 \mathrm{a}$ & $3.31 \mathrm{a}$ & 6.45 \\
\hline Yes & 144 & $80 \mathrm{~b}$ & 126 & 47 & $104 \mathrm{a}$ & $309 a$ & 38 & $46 a$ & $11542 \mathrm{a}$ & $4117 \mathrm{a}$ & 0.35 & $16 \mathrm{~b}$ & $1.75 \mathrm{~b}$ & $1.13 \mathrm{~b}$ & $2.91 \mathrm{~b}$ & 4.50 \\
\hline CV (\%) & 15.2 & 2.3 & 1.3 & 5.3 & 6.5 & 17.3 & 12.6 & 4.3 & 11.8 & 16.1 & 10.4 & 38.2 & 46.7 & 77.3 & 27.0 & 184.4 \\
\hline
\end{tabular}

$\uparrow \mathrm{COT}=$ stand count after emergence; DTH=days to heading; DTM=days to maturity; GFP=grain filling period; PHT=plant height; SPM=spike per meter square; KPS=Kernel per spike; TKW = Thousand kernel weight; $\mathrm{BYLD}=$ biological yield; $\mathrm{GYLD}=$ grain yield; $\mathrm{HI}=$ harvest index; $\mathrm{IND}=$ insect damage; $\mathrm{SCL}=$ scald disease score; $\mathrm{NEB}=$ net blotch disease score; $\mathrm{SPB}=$ spot blotch disease score; RUS=rust disease score.

$\$$ Means followed by the same letter within column for a factor are not statistically different from each other at $\mathrm{P}<0.05$.

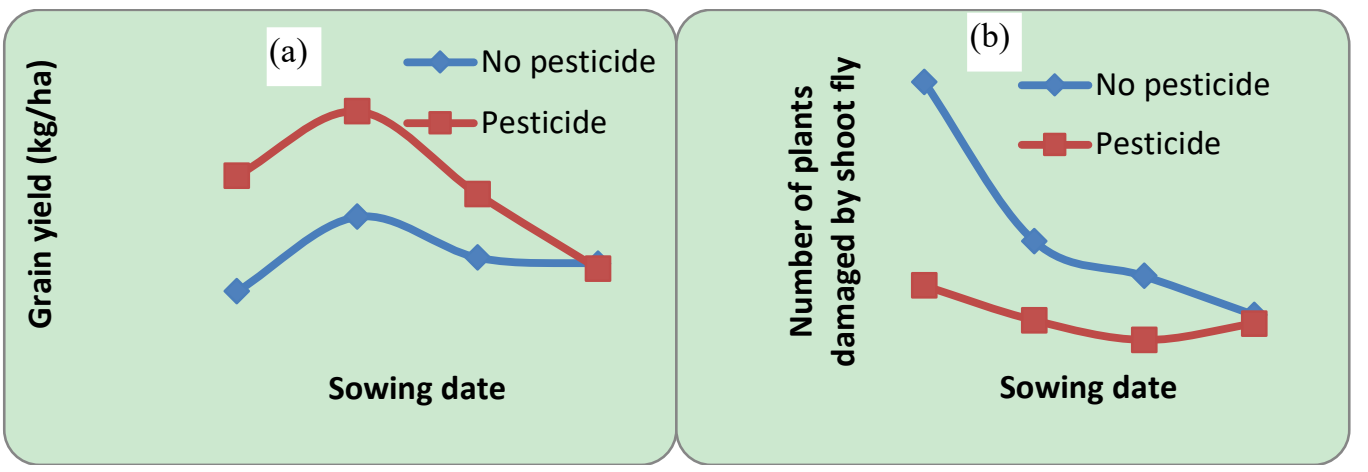

Figure 1. The relationship between sowing date and (a) grain yield, (b) number of plants damaged by shoot fly in barley grown under two crop protection levels in 2010 at Holetta, Ethiopia. (Note: s1= June 15; s2= June 26; s3= July; s4= July 18). 